\title{
Wide Skin Excision
}

National Cancer Institute

\section{Source}

National Cancer Institute. Wide Skin Excision. NCI Thesaurus. Code C48608.

Surgical excision of diseased skin tissue with a border of healthy tissue surrounding the lesion. It is often used as a treatment for skin cancers. The marg in of the healthy tissue may range from a few millimeters for small cancers up to around $15 \mathrm{~mm}$ for larger cancers. 